\title{
The Jewish Revolution in Belorussia: Economy, Race, and Bolshevik Power
}

BY

\author{
ADAM COMAN
}

\begin{abstract}
Andrew Sloin
The Jewish Revolution in Belorussia: Economy, Race, and Bolshevik Power Bloomington, Indianapolis: Indiana University Press, 2017. 331 p
\end{abstract}

Andrew Sloin's "The Jewish Revolution in Belorussia" is an original and illuminating work on the actions, reactions, and fate of the Jewish population in Belorussia, covering the period from the outbreak of the Bolshevik revolution to the outset of the Stalin revolution. The work's novelty lies in several aspects, the most evident of which is its focus on Jewish workers, artisans, local revolutionaries, "speculators" and petty criminals, and illiterate and semiliterate Jews (p. 24).

The decision to focus on lower-class, socially marginal Jews serves two purposes: firstly, it provides fresh insight into the lives and beliefs of an all too often disregarded social group, given the common predilection to study "atypical [and] émigré intellectuals". This penchant, Sloin argues, serves an apologetic historical approach which seeks to minimise the extent of Jewish participation in the revolution. As a result of this approach, the second purpose which Sloin's focus on this neglected group serves, is to emphasise the initial cooperation of large portions of the Jews of Belorussia with the emerging Bolshevik regime. However, Sloin studies not only the actions and ideas of revolutionary Jews - whether Bundists, Bolshevik, or Trotskyists - but through the programmes and reports of evsektsiia, also the changing reactions to Bolshevism of anti-revolutionary Jews (whether traditional, religious, or Zionist).

Sloin takes a rather Marxist socioeconomic approach in order to demonstrate how economic and social factors swept a large number of Belorussian Jews into the Bund at the beginning of the 20th century and drove them into the Bolshevik ranks following the revolution. Economic factors, often articulated through the prism of Horkheimer and the Frankfurt School, are also used to explain the rise of antisemitism, and the ultimate demise of the so-called Jewish revolution, as " $\mathrm{t}$ ] he fate of the Jewish Revolution was tied to the fate of the NEP and structured by 
the policies of that era" (p. 245). While this viewpoint illuminates the possibilities and place of the Jews in revolutionary Belorussia, its application to the relations between Jews and non-Jews and the rise of antisemitism during the anti-Trotskyist wave, is somewhat limiting, and lacks deeper investigations into ideological, traditional, and religious factors.

Nonetheless, Sloin's account of the Jewish-Bolshevik relations is original and convincing. Establishing power in Belorussia, the Bolsheviks required not only Jewish support, but also that of the Belorussian and Polish populations. As a result, Belorussia granted official status to Belorussian, Russian, Polish and Yiddish - a tolerant approach, unparalleled at the time. The acceptance and encouragement of different national identities was exceptional not only from the point of view of the anti-national communist ideology, but also in comparison to the majority of interwar European states, in which national chauvinism was the norm. For the Jewish Bundists-turned-Bolshevik revolutionaries, this was an opportunity to create a new national-Jewish culture which would replace both traditional, religious Judaism, as well as present itself as an alternative to Zionism and other rivalling Jewish ideologies.

The body responsible for Jewish integration in Bolshevik society was the evsektsiia, and Sloin presents a very interesting narrative of its evolution. The first evsektsii leadership was comprised of predominantly Minsk Bundists who became Bolsheviks. This leadership sought to recruit Jews to the revolution by creating a new Jewish-Bolshevik identity, which would combine Yiddish culture and heritage assets (such as the works of I. L. Peretz) with communist ideology. This period saw the formation and support of Yiddish theater, press, publishing houses, etc.

In 1926, however, Abram Beilin, a "provincial outsider" with little interest in Jewish affairs, was made Head of the evsektsiia (p. 139). This appointment marked a shift in the evsektsiia programme, as it sought a deeper Jewish integration in Bolshevik society and saw Yiddish culture as a means for this integration, rather than an aim in itself. While not completely discarding urban Yiddish cultural enterprises, Beilin's evsektsiia focused on the shtetl, where it sought to win over the religious, traditional Jewish population by strengthening the economic status of the kustari (cottage producers), opening schools, and spreading haskole, the Yiddish version of 19th century Jewish enlightenment (Haskalah).

Both of these periods are what Sloin terms "the Jewish revolution". However, whereas this story of the Jews in the early years of Bolshevik Belorussia is indeed captivating, it is questionable first of all whether "The Jewish Revolution in Belorussia" is the appropriate title for the volume, and secondly, whether the period of Jewish resurgence actually constitutes a revolution. 
Regarding the first question, the answer is most probably negative - Sloin's work covers a wider, and much more interesting story, the bulk of which is the everchanging political ideology with which Jewish revolutionaries, for the most part, had to fence and accommodate. The Bolsheviks' need to recruit Jews to the revolution warranted that initially, past Bund membership was viewed positively, as it attested to a long-standing revolutionary consciousness. The assimilation of the Bundists in the Bolshevik party marked the beginning of the "golden age" for Jewish revolutionaries. This Jewish-Bolshevik honeymoon endured both the economic crises of War Communism, as well as the early perils of the NEP Jewish revolutionaries sided with official Bolshevik policy in condemning the ambiguous crime of speculation (committed overwhelmingly by Jews), and combating ongoing religious practices on the one side, and Zionism on the other. In return, the Jewish revolutionaries enjoyed widespread assimilation through proletarianisation, as well as state and party support in establishing a new JewishBolshevik identity.

One of the most intriguing examples of the unusual outcomes of this experimental policy is the strange case of Turov, a religious shtetl, in which the community leaders attempted to constitute a "soviet of synagogues" which would run local institutions (p. 131-2). The rich variety of such stories, as well as the rapid change of policies which led to an anti-Bundist wave, followed by an antiTrotskyist wave (which already exhibited signs of antisemitism), followed by recurring antisemitic episodes, all of which were influenced by the NEP crises and the transition to Stalinism, overshadows the brief, albeit fascinating, JewishBolshevik experiment, as it is depicted in the book.

The second question, whether the Jewish-Bolshevik experiment in Belorussia is in fact a revolution, is more complicated. According to Sloin, the achievements of the Jewish revolution were "remarkable: the Bolshevik state opened unprecedented numbers of secular schools for Jewish children; removed restrictions on university entry for Jewish students; established schools and informal programmes for Jewish workers; formed and supported state- and party-run literacy centres" (p. 245).

While this list of achievements is indeed remarkable, it is debatable whether it qualifies a revolution. As Sloin himself notes, many of the efforts and accomplishments (but also the difficulties and disappointments) of the Bolshevik haskole were attempted in the 19th century by the maskilim of western Europe. The desire to bring forward, as well as sever the ties of the traditional, religious, Jewish population with the "backward" world of the shtetl, was the desire of Jewish groups since the beginning of the 19th century. It was shared, with greater and lesser levels of implementation success, by the maskilim, social democrats, communists, Bundists, and Zionists. 
Moreover, the confused nature of the "revolution", as the Turov shtetl illustrates, defies the idea that the shtetl Jews cooperated with the haskole efforts. As Sloin makes clear throughout his work, religious, Zionist, and anti-revolutionary Jews in Belorussia, needed to find original and effective ways to contend with the threats and pressures of Bolshevism. Given the social heterogeneity of the Jewish population in Belorussia, which Sloin repeatedly emphasises, it is questionable whether the evsekstiia's efforts actually produced a new "Jewish-Bolshevik", and if they did, the biggest question remains in what ways were Belorussian Jews different from other Soviet Jews following this revolution.

Nonetheless, "The Jewish Revolution in Belorussia" is a very valuable work on the complicated reality both revolutionary and non-revolutionary Jews experienced in Belorussia. Sloin's work chronicles the role Jews played in shaping the Bolshevik revolution in Belorussia, but also the way the revolution shaped them, ideologically, socially, and economically, from the outbreak of the revolution, through the consecutive years of War Communism and NEP, until the consolidation of Stalinism. The story of the Jews and the Bolshevik revolution in Belorussia is interesting not only as a micro-case study of the Jews and the Bolshevik revolution. Rather, given the exceptionality of the BSSR's relation to the four main nations which populated it - Belorussians, Russians, Jews, and Poles - it is also the story of the opportunities and disappointments the Belorussian Jews experienced during the formative years of Bolshevism.

What distinguishes the Belorussia of this period of time from other socialist republics is the state's acceptance of the four nations, an acceptance most clearly embodied in the equal status their languages enjoyed in the state. This exceptional approach constituted Belorussia "an ideal-typical site to carry out this grand experiment in overcoming nationalist barbarism through the democratic promotion of nationality" (p. 241). As the book shows, the ultimate failure of this experiment lay not in the local politics and relations of the nations living in Belorussia, but in the destructive pressures of the global ideologies and politics of the first half of the 20 th century. 